\title{
Evaluasi Program Badan Usaha Milik Desa (BUM DESA) Oleh Dinas Pemberdayaan Masyarakat dan Desa di Kabupaten Karawang
}

\author{
Hanny Purnamasari, \\ Program Studi Ilmu Pemerintahan, Fakultas Ilmu Sosial dan Ilmu Politik, Universitas Singaperbangsa \\ Karawang \\ hanny.purnamasari@fisip.unsika.ac.id

\section{Rachmat Ramdani} \\ Program Studi Ilmu Pemerintahan, Fakultas Ilmu Sosial dan Ilmu Politik, Universitas Singaperbangsa \\ Karawang \\ denifauziramdani@gmail.com
}

\begin{abstract}
Abstrak
Pemerintah Daerah Kabupaten Karawang telah membuat peraturan Bupati Nomor 51 Tahun 2015 Tentang Pendirian, Pengurusan, Pengelolaan dan Pembubaran Usaha Milik Desa. Berdasarkan peraturan Bupati Karawang tersebut dalam pasal 1 menyatakan bahwa Badan usaha milik desa selanjutnya disebut Bum Desa adalah badan usaha yang seluruh atau sebagian besar modalnya dimiliki oleh Desa melalui penyertaan modal secara langsung yang berasal dari kekayaaan Desa yang dipisahkan guna menggelola aset, jasa layanan, dan usaha lainnya untuk sebesar-besarnya kesejahteraan masyarakat desa. Penelitian ini menggunakan teori Dunn (2003) yang meliputi efektivitas, efisisensi, kecukupan, pemerataan, responsivitas dan ketepatan dengan tujuan untuk mengetahui bagaimana evaluasi program BUM Desa oleh Dinas Pemberdayaan Masyarakat dan Desa di Kabupaten Karawang. Metode yang digunakan dalam penelitian ini adalah metode deskriptif dengan pendekatan kualitatif. Hasil penelitian menunjukan bahwa evaluasi program BUM Desa oleh Dinas Pemberdayaan Masyarakat dan Desa di Kabupaten Karawang masih belum efektif. Hal ini terlihat dari belum tercapainya tujuan pendirian BUM Desa.
\end{abstract}

Kata kunci: Evaluasi Program, DPMD, BUM Desa, Karawang

\section{Abstract}

The Karawang regency government has made a regent regulation number 51 of 2015 concerning the establishment, management, management and dissolution of village-owned businesses. Based on the Karawang Regent's regulation in article 1 states that the village-owned enterprise, hereinafter referred to as Village Bum, is a business entity that is wholly or most of its capital owned by the Village through direct equity participation from village assets that are separated to manage assets, services, and other efforts for the maximum welfare of the village community. This study uses Dunn's theory (2003) which includes effectiveness, efficiency, adequacy, equity, responsiveness and accuracy with the aim of knowing how to evaluate the BUM Desa program 
by the Office of Community and Village Empowerment in Karawang District. The method used in this research is descriptive method with a qualitative approach. The results showed that the evaluation of the BUM Desa program by the Office of Community and Village Empowerment in Karawang District was not yet effective. This can be seen from the achievement of the purpose of establishing BUM Desa.

Keywords: Program Evaluation, DPMD, BUM Desa, Karawang

\section{Pendahuluan}

Pemerintah Daerah Kabupaten Karawang telah membuat peraturan Bupati Nomor 51 Tahun 2015 Tentang Pendirian, Pengurusan, Pengelolaan dan Pembubaran Usaha Milik Desa. Berdasarkan peraturan Bupati Karawang tersebut dalam pasal 1 menyatakan bahwa Badan usaha milik desa selanjutnya disebut Bum Desa adalah badan usaha yang seluruh atau sebagian besar modalnya dimiliki oleh Desa melalui penyertaan modal secara langsung yang berasal dari kekayaaan Desa yang dipisahkan guna menggelola aset, jasa layanan, dan usaha lainnya untuk sebesar-besarnya kesejahteraan masyarakat desa.

Sumber dana BUM Desa Kabupaten Karawang telah diatur dalam Peraturan Bupati Nomor 2 Tahun 2017 Tentang Tata Cara Pembagian dan Penetapan Rincian Dana Desa Setiap Desa Di Kabupaten Karawang, berdasarkan peraturan Bupati Karawang menyatakan dalam pasal 16 pendirian dan pengembangan BUM Desa bersama usaha ekonomi produktif sebesar 15\% kegunaannya untuk antara lain, pendirian Bumdes bersama, penyertaan modal BUM Desa bersama dan penguatan permodalan BUM Desa berasama. Besaran yang diperoleh Desa rata-rata per desa alokasi sebesar 120- 140 Juta untuk kegiatan BUM Desa.

Namun, pelaksanaan dari BUM Desa di Karawang berdasarkan info dari Fakta Jabar (2018) menuai permasalahan diantaranya, adanya penyalahgunaan dana BUM Desa di Desa Telukjaya Kecamatan Pakisjaya dana peruntukan untuk Bum Desa digunakan untuk menggadai sawah oleh kepala desanya. Seharusnya penggunaan alokasi dana BUM Desa harus sesuai dengan peruntukan untuk kegiatan pendayagunaan ekonomi lokal dengan berbagai ragam jenis potensi yang ada di Desa. Selain penyalahgunaan dana BUM Desa oleh pemerintah Desa terdapat permasalahan lainya seperti transparansi anggaran BUM Desa dan kejelasan peruntukan kegiatan BUM Desa.

Peristiwa tersebut terjadi di Desa Ciwaringin Kecamatan Lemahabang masyarakat menuntut transparansi anggaran BUM Desa dan kejelasan peruntukan program BUM Desa, berdasarkan informasi yang diperoleh melalui media online Tv Berita (2018) permasalahan BUM Desa di Desa Ciwaringin program BUM Desa simpan pinjam hanya dimanfaatkan dan diberikan kepada keluarga kepala desa saja sedangkan masyarakat yang ingin meminjam uang BUM Desa tersebut sangat sulit. Berdasarkan uraian di atas dapat diartikan bahwa tujuan pendirian BUM Desa untuk meningkatkan perekonomian masyarakat desa dan peningkatan pendapatan asli desa belum tercapai. 


\section{Kerangka Teori}

Untuk dapat memahami secara mendalam tentang pengertian pemberdayaan maka perlu mengkaji beberapa pendapat para ilmuwan yang memiliki komitmen terhadap pemberdayaan masyarakat. menjelaskan bahwa pemberdayaan adalah suatu proses pribadi dan sosial, suatu pembebasan kemampuan pribadi, kompetensi, kreatifitas dan kebebasan bertindak. Sedangkan Ife (1995) mengemukakan bahwa pemberdayaan mengacu pada kata "empowerment", yang berarti memberi daya, memberi "power" (kuasa), kekuatan, kepada pihak yang kurang berdaya. Payne (1997) menjelaskan bahwa pemberdayaan pada hakekatnya bertujuan untuk membantu klien mendapatkan daya, kekuatan dan kemampuan untuk mengambil keputusan dan tindakan yang akan dilakukan dan berhubungan dengan diri klien tersebut, termasuk mengurangi kendala pribadi dan sosial dalam melakukan tindakan (Hikmawan, 2014). Orang-orang yang telah mencapai tujuan kolektif diberdayakan melalui kemandiriannya, bahkan merupakan "keharusan" untuk lebih diberdayakan melalui usaha mereka sendiri dan akumulasi pengetahuan, ketrampilan serta sumber lainnya dalam rangka mencapai tujuan tanpa tergantung pada pertolongan dari hubungan eksternal. Secara lebih rinci Slamet (2003), menekankan bahwa hakikat pemberdayaan adalah bagaimana membuat masyarakat mampu membangun dirinya dan memperbaiki kehidupannya sendiri. Istilah mampu disini mengandung makna berdaya, paham, termotivasi, memilki kesempatan, melihat dan memanfaatkan peluang, berenergi, mampu bekerja sama, tahu sebagai alternative, berani mengambil resiko, mampu mencari dan menangkap informasi serta mampu bertindak sesuai dengan inisiatif. Sedangkan indikator pemberdayaan menurut suharto (2009), paling tidak memiliki empat hal, yaitu kegiatan yang terencana dan kolektif, memperbaiki kehidupan masyarakat, perioritas bagi kelompok lemah atau kurang beruntung, serta dilakukan melalui program peningkatan kapasitas. Pemberdayaan desa adalah upaya untuk meningkatkan kemampuan dan potensi yang dimiliki oleh suatu desa sehingga desa tersebut dapat mengoptimalisasikan sumber daya yang ada secara maksimal untuk bertahan dan mengembangkan desa secara mandiri (Hikmawan, 2017b). Pemberdayaan desa adalah program yang bertujuan untuk mempercepat penanggulangan kemiskinan melalui pemberdayaan masyarakat, penyedian Dana Usaha Desa (DUD) dan penguatan koordinasi serta sinergi sektoral dalam pembangunan desa secara partisipatif

Pembahasan modal atau biaya BUM Desa dilaksanakan pada saat pembentukan

BUM Desa atau pada saat pembahasan anggaran pendapatan dan belanja desa (APBDES) untuk selanjutnya di atur dalam Anggaran Dasar dan Anggaran Rumah Tangga BUM Desa. Adapun sumber pemodalan BUM Desa sebagai berikut:

a. Pendapatan asli desa (PAD) 
b. Bantuan Pemerintah baik dari APBN, APBD Provinsi maupun dari APBD Kabupaten Karawang.

c. Bantuan atau sumber lainya yang sah dan tidak mengikat

d. Bantuan berupa kerjasama dengan pihak swasta/pihak ketiga

e. Pinjaman dari lembaga keuangan atau perbankan yang disetujui melalui musyarawarah desa

f. Penyertaan modal pada BUM Desa ditetapkan dengan peraturan Desa dibahas pada saat pembahasan anggaran pendapatan dan belanja desa atau saat pembahasan perubahan anggaran pendapatan belanja desa. (Sumber: Pedoman Pelaksana Teknis BUM Desa Kabupaten Karawang)

Ketentuan yang tertuang dalam dokumen Pedoman Pembentukan dan Pengelolaan BUM Desa diperuntukan bagi Pemerintah Desa di Kabupaten Karawang sebagai standar dalam pelaksanaan pembinaan, fasilitasi oleh Dinas Pemberdayaan Masyarakat dan Desa Kabupaten Karawang. Hal yang diatur dalam dokumen pedoman pembentukan dan pengelolaan BUM Desa yaitu aspek pemodalan.

\section{Metode Penelitian}

Dalam penelitian ini peneliti menggunakan metode deskriptif (Faedlulloh, 2018) dengan pendekatan kualitatif dimana dalam penelitian yang dilakukan bersifat deskriptif yaitu untuk mengetahui atau menggambarkan kenyataan dari kejadian yang diteliti sehingga memudahkan peneliti untuk mendapatkan data yang objektif dalam rangka untuk bagimana evaluasi program Badan Usaha Milik Desa (BUM Desa) di Dinas Pemberdayaan Masyarakat dan Desa di Kabupaten Karawang.

\section{Hasil dan Diskusi}

Menganalisis Evaluasi program Badan Usaha Milik Desa di Dinas Pemberdayaan Masyarakat dan Desa di Kabupaten Karawang merupakan fenomena yang menarik untuk penelitian dalam kajian Ilmu Pemerintahan. Sumber data yang di gunakan oleh peneliti berupa tindakan dan kata-kata yang didapatkan melalui proses wawancara mendalam dan observasi lapangan. Dalam penelitian ini, sumber data terdapat sumber data primer yang berupa kata-kata dan tindakan orang-orang yang diamati atau wawancara mendalam. Sumber data sekunder berupa dokumendokumen yang berkaitan dengan objek penelitian.

Penelitian tentang evaluasi program BUM Desa di Dinas Pemberdayaan Masyarakat dan Desa Kabupaten Karawang membutuhkan komitmen antara pemerintah daerah Kabupaten Karawang dengan Pemerintah Desa untuk melaksanakan pemberdayaan masyarakat pedesaan melalui program BUM Desa. Pelaksanaan BUM Desa di Kabupaten Karawang menjadi sebuah fenomena sosial ekonomi serta politik yang dirasakan oleh masyarakat pedesaan. Pelaksanaan program BUM Desa oleh Dinas Pemberdayaan Masyarakat dan Desa Kabupaten Karawang yang dirasakan hanya sebatas pada pembentukan kelembagaan dari BUM Desa sehingga 
masyarakat menilai program dari BUM Desa belum optimal. Berbagai kegiatan yang telah dilakukan oleh pemerintah daerah melalui Dinas Pemberdayaan Masyarakat dan Desa Kabupaten Karawang dengan pemerintah desa serta masyarakat dalam pelaksanaan program BUMDES namun masih belum membuahkan hasil yang maksimal. Permasalahan yang dirasa menjadi sebuah masalah yang klasik karena yang tidak bisa dihindari oleh setiap dinas yang berhubungan dengan dukungan sumber daya finansial dari pemerintah Kabupaten Karawang.

Dinas Pemberdayan Masyarakat Desa Kabupaten Karawang memiliki program dan kegiatan yang menjadi tujuan dalam jangka waktu 5 (lima) tahun kedepan. Pertama, gerakan desa mandiri dengan adanya berbagai macam bantuan keuangan yang diberikan kepada desa, diharapkan pemerintah desa dapat mengelola bantuan tersebut dengan peraturan yang berlaku. Kedua, pendampingan dan penguatan kapasitas kelembagaan dan aparatur desa.

Ketiga, pengembangan Badan usaha milik desa, Keempat pengembangan dan penguatan sarana dan prasarana infrastruktur dasar perdesaan dan Kelima, peningkatan kualitas SDM aparatur desa dan pengutan lembaga ekonomi desa, kesehatan yang berbasis masyarakat desa serta partisipasi masyarakat dalam membangun desa dengan memanfaatkan teknologi tepat guna. Dalam hal tata kelola BUM Desa merupakan salah satu program unggulan dari Dinas Pemberdayaan Masyarakat dan Desa Kabupaten Karawang.

\section{Tabel 1}

Hasil Evaluasi BUM Desa 2018

\begin{tabular}{|c|c|c|c|}
\hline No & Uraian & Jumlah & Keterangan \\
\hline 1 & $\begin{array}{l}\text { Jumlah BUM Desa yang } \\
\text { diundang }\end{array}$ & $\begin{array}{l}297 \text { Desa / BUM } \\
\text { Desa }\end{array}$ & $\begin{array}{l}\text { Hasil kinerja } \\
\text { BUM Desa } 2018\end{array}$ \\
\hline 2 & $\begin{array}{l}\text { Jumlah BUM } \\
\text { hadir }\end{array}$ & $\begin{array}{l}278 \text { Desa / BUM } \\
\text { Desa }\end{array}$ & $\begin{array}{l}\text { Hasil kinerja } \\
\text { BUM Desa } 2018\end{array}$ \\
\hline 3 & $\begin{array}{l}\text { Jumlah BUM Desa yang tidak } \\
\text { hadir }\end{array}$ & $\begin{array}{l}19 \text { Desa / BUM } \\
\text { Desa }\end{array}$ & $\begin{array}{l}\text { Hasil kinerja } \\
\text { BUM Desa } 2018\end{array}$ \\
\hline 4 & $\begin{array}{l}\text { BUM Desa hadir tetapi tidak } \\
\text { mengumpulkan berkas }\end{array}$ & $\begin{array}{l}20 \text { Desa / BUM } \\
\text { desa }\end{array}$ & $\begin{array}{l}\text { Hasil kinerja } \\
\text { BUM Desa } 2018\end{array}$ \\
\hline 5 & $\begin{array}{l}\text { BUM Desa hadir tidak } \\
\text { melengkapi berkas }\end{array}$ & $\begin{array}{l}106 \text { Desa / BUM } \\
\text { Desa }\end{array}$ & $\begin{array}{l}\text { Hasil kinerja } \\
\text { BUM Desa } 2018\end{array}$ \\
\hline 6 & $\begin{array}{l}\text { BUM Desa yang hadir dan } \\
\text { melengkapi berkas }\end{array}$ & $\begin{array}{l}152 \text { Desa / BUM } \\
\text { Desa }\end{array}$ & $\begin{array}{l}\text { Hasil kinerja } \\
\text { BUM Desa } 2018\end{array}$ \\
\hline
\end{tabular}


Sumber: Dinas Pemberdayaan Masyarakat Desa 2018

Berdasarkan dari data tabel di atas hasil dari evaluasi BUM Desa 2018 yang dilaksanakan oleh Bidang Pemberdayaan Usaha Ekonomi Masyarakat Dinas Pemberdayaan Masyarakat Desa Kabupaten Karawang dari jumlah 297 Desa belum semua melengkapi pemberkasan kelembagaan Bumdes dari setiap Desa, sedangkan Desa yang sudah melengkapi pemberkasan terdapat 152 Desa / BUM Desa masih terdapat banyak Desa / BUM Desa yang belum melengkapi pemberkasan. Dari kegiatan hasil evaluasi kinerja BUM Desa 2018 yang dilakukan oleh Dinas Pemberdayaan Masyarakat dan Desa Kabupaten Karawang yaitu dengan kegiatan sebagai berikut:

a. Pemeriksaan pengadministrasian laporan keuangan BUM Desa Tahun 2015-2017

b. Klarifikasi Dana BUM Desa yang turun dari rekening Pemerintahan Desa dengan

Dana BUM Desa yang ditransfer oleh Kepala Desa yang bersumber dari Dana Desa (APBN)

c. Pemeriksaan kelengkapan surat keputusan kepenggurusan BUM Desa

d. Klarifikasi jenis usaha BUM Desa yang dilakukan.

Aspek-aspek teori operasional tersebut berasal dari teori Evaluasi Kebijakan Publik yang dikemukakan oleh Dunn (2003) yang menjelaskan bahwa evaluasi kebijakan secara sederhana berkenaan dengan produksi informasi mengenai nilai-nilai atau manfaat-manfaat hasil kebijakan. Ketika kebijakan publik tersebut bermanfaat bagi masyarakat sebagai penilaian atas penyelesaian masalah maka hasil tersebut memberi sumbangan pada tujuan dan sasaran bagi evaluator (Hikmawan \& Hidayat, 2016). Berdasarkan hasil temuan penelitian menunjukan terdapat aspek efektivitas, efisien dan responsivitas kemudian selanjutnya menggumpulkan data yang dibutuhkan yang berkaitan dengan objek penelitian, maka selanjutnya akan menguraikan dan menganalisis temuan penelitian lapangan.

Penilaian terhadap efektivitas ditunjukan untuk menjawab ketepatan waktu pencapaian hasil/tujuan untuk mengukur efektivitas program dengan mengunakan parameternya adalah ketepatan waktu. Menurut Dunn (2003) menyatakan bahwa "efektivitas berhubungan dengan alternatif mencapai hasil yang diharapkan atau mencapai tujuan dari diaadakan kebijakan.

Dinas Pemberdayaan Masyarakat dan Desa sebagai organisasi Perangkat Daerah yang mempunyai kewenangan menanggani pemberdayaan masyarakat usaha ekonomi masyarakat melalui pengelolaan Badan Usaha Milik Desa kepada Pemerintahan Desa di Kabupaten Karawang.

Hasil penelitian lapangan dan wawancara mendalam dengan informan maka peneliti dapat melihat bahwa evaluasi program BUM Desa di Kabupaten Karawang belum berjalan dengan efektif. Parameter dari efektivitas program yaitu ketetapan waktu, berkaitan dengan pelaksanaan program BUM Desa di Kabupaten Karawang telah dibentuk pada tahun 2015 sebagai acuannya sudah dibuatkan regulasi Peraturan 
Bupati Kabupaten Karawang sebagai bentuk respon dari Pemerintah Daerah Karawang lahirnya regulasi tentang Undang-Undang Nomor 6 Tahun 2014 Tentang Pemerintahan Desa, namun pelaksanaan BUM Desa di Kabupaten Karawang hanya sebatas pembentukan kelembagaan.

Dalam UU tersebut pemerintahan desa pada pasal 87 mengamanatkan bahwa Desa dapat mendirikan BUM Desa yang dapat menjalankan usaha bidang ekonomi. Pemerintah daerah Kabupaten Karawang melalui Dinas Pemberdyaan Masyarakat dan Desa sebagai pelaksana teknis untuk membentuk kelembagaan BUMDES dari setiap Desa yang ada di Kabupaten Karawang. Dari Jumlah pemerintah Desa di Kabupaten Karawang terdiri dari 297 Desa sedangkan yang sudah melengkapi berkas sekitar 152 Desa masih banyak BUM Desa yang belum melengkapi berkas yang sesuai dengan format yang disediakan oleh Undang-Undang Nomor 6 Tahun 2014 Tentang Pemerintahan Desa Kabupaten Karawang.

Penilaian terhadap efisiensi ditunjukan untuk menjawab pengorbanan yang minim usaha hasil maksimal untuk mengukur efisiensi program dengan menggunakan parameternya adalah biaya, keuntungan dan manfaat. Dunn (2003) mempertegas efisiensi berkenaan dengan jumlah usaha yang diperlukan untuk menghasilkan tingkat efektivitas tertentu. Kemudian, Dunn mengkategorikan bahwa kebijakan publik yang mencapai efektivitas tertinggi dengan biaya kecil dinamakan dengan efisien.

BUM Desa merupakan lembaga baru yang perkembanganya masih menemui kendala terutama berkaitan dengan pemahaman masyarakat tentang kelembagaan BUM Desa. Hal ini membuat BUM Desa beserta unit usaha dan program kegiatan yang diselenggarakan belum mendapat cukup dukungan dari warga desa. Saat ini yang paling penting adalah mengupayakan tumbuhnya usaha desa yang mampu memberikan manfaat bagi warga baik secara langsung atau tidak langsung.

Pembiayaan pelaksanaan dari BUM Desa sudah diatur secara teknis dari mana saja sumber pendapatan untuk pembiayaan program BUM Desa tersebut. Dari aspek biaya untuk pelaksanaan BUM Desa memiliki beberapa sumber seharusnya pelaksanaan BUM Desa sudah berjalan dengan efisien tidak terkendala oleh dari mana sumber biaya pelaksanaan dari BUM Desa, BUM Desa merupakan amanat konstitusi sehingga pemerintah melalui APBN maupun APBD provinsi dan Kabupaten/Kota menjadi bagian sumber pembiayaan dari pelaksanaan BUM Desa tersebut.

Dari hasil penelitian dan wawancara mendalam diatas maka dapat dilihat bahwa efisien program BUM Desa di Kabupaten Karawang yang dilakukan oleh Dinas Pemberdayaan Masyarakat dan Desa dalam fasilitator pelaksanaan BUM Desa di Kabupaten Karawang belum menunjukan efisien pelaksanaan program BUM Desa masih banyak ditemukan kelemahan yang berkaitan dengan pembiyaan pelaksanaan BUM Desa serta masyarakat belum sepenuhnya dapat menikmati dari manfaat program BUM Desa. BUM Desa sebagai lembaga independen diluar struktur pemerintahan desa namun dalam pelaksanaannya masih di dominasi oleh kekuatan 
politik pemerintahan desa terutama kepala Desa masih dominasi kebijakan dari program BUM Desa.

Yang dimaksud kecukupan adalah berkenaan dengan seberapa jauh suatu kebijakan tingkat efktifitasnya memuaskan kebutuhan (Hikmawan, 2017a), nilai, atau kesempatan yang menimbulkan adanya masalah. Dimana dalam suatu kebijakan terdapat alternatif apa yang akan dilakukan bila kebijakan telah diimplementasikan. Dengan kata lain seberapa jauh pencapaian hasil yang diinginkan telah memecahkan masalah. Indikator penilaiannya adalah pelaksana kebijakan sebuah kebijakan akan dapat berjalan dan mencapai tujuannya apabila di laksanakan dengan baik. Pelaksana kebijakan merupakan suatu unsur yang memiliki peran paling besar dalam pelaksanaan suatu kebijakan untuk mendorong pada tercapainya tujuan yang diinginkan.

Hasil temuan peneliti di lapangan, BUM Desa yang ada di Kabupaten Karawang belum dapat mencapai tujuan awal pendiriannya sehingga kecukupan Dalam Evaluasi Program Badan Usaha Milik Desa di Dinas Pemberdayaan Masyarakat dan Desa Di Kabupaten Karawang belum optimal, hal ini terlihat dari BUM Desa yang belum dapat meningkatkan perekonomian desa, belum dapat mengoptimalkan aset desa agar bermanfaat untuk kesejahteraan desa, belum dapat meningkatkan usaha masyarakat dalam pengelolaan potensi ekonomi desa, belum dapat mengembangkan rencana kerja sama usaha antar desa dan/atau dengan pihak ketiga, belum dapat menciptakan peluang dan jaringan pasar yang mendukung kebutuhan layanan umum warga, belum dapat membuka lapangan kerja, belum dapat meningkatkan kesejahteraan masyarakat melalui perbaikan pelayanan umum, serta belum dapat meningkatkan pendapatan masyarakat desa dan Pendapatan Asli Desa.

pemerataan adalah berkenaan dengan pemerataan distribusi manfaat dari suatu kebijakan. Yang dilihat dari pemerataan adalah apa apakah manfaat distribusi merata kepada kelompok-kelompok yang berbeda, dimana ada tiga unsur kelompok dari kebijakan yang harus diperhatikan yaitu kelompok pemerintah sebagai pembuat kebijakan, kelompok swasta sebagai objek kebijakan dan kelompok masyarakat sebagai impact dari kebijakan.

Hasil temuan peneliti di lapangan pemerataan Dalam Evaluasi Program Badan Usaha Milik Desa di Dinas Pemberdayaan Masyarakat dan Desa Di Kabupaten Karawang belum optimal karena belum terasanya manfaat program BUM Desa untuk masyarakat sebagai sasaran dari program. Hal ini terjadi karena kurangnya koordinasi antara Kepala Desa sebagai pembina BUM Desa dalam implementasinya, seharusnya implementasi harus sesuai prosedur dan ketentuannya (Widiyanto, Hikmawan, \& Riswanda, 2019). BPD sebagai pengawas kinerja Pemerintah Desa dalam membina pengelolaan BUM Desa dan Dinas Pemberdayaan Masyarakat dan Desa sebagai pelaksana teknis dalam pembinaan dan pengawasan BUM Desa.

Penilaian terhadap tersponsivitas ditunjukan untuk mengetahui rencana atau program kebijakan sesuai dengan preferensi keinginan dari target group. Responsivitas dalam kebijakan publik dapat dipahami sebagai respon dari suatu 
program. Responsivitas sebagai tanggapan dari sasaran atas pelaksanaan program. Lebih lanjut Dunn (2003) responsivitas sejauh mana program dari kebijakan dapat memuaskan kebutuhan, preferensi atau nilai-nilai kelompok-kelompok masyarakat dan sesuai dengan menghargai perbedaan masing-masing (Hikmawan, 2017b).

Responsivitas dari masyarakat implikasi dari kebijakan sudah mulai dapat dirasakan dalam bentuk respon positif yang berupa dukungan maupun respon yang wujud negara yang beruapa penolakan. Kemudian Dunn (2003) mempertegas dari kriteria responsivitas sebagai analisis yang dapat memuaskan dari kriteria-kriteria lainnya seperti efektivitas, efisiensi, kecukupan dan kesamaan) evalauasi suatu program dianggap gagal apabila belum mampu menanggapi kebutuhan aktul dari kelompok yang seharusnya ada perubahan dari program tersebut.

Evaluasi program BUM Desa di Kabupaten Karawang masyarakat dianggap sebagai responsivitas dari pelaksanaan program BUM Desa karena masyarakat sebagai target group dari pelaksanaan BUM Desa tersebut. Responsivitas dari masyarakat sebagai pihak target grup yang turut terlibat dalam membangunan perekonomian kemasyarakatan.

Sesuai dengan Peraturan Bupati Karawang Nomor 53 Tahun 2016 tentang Kedudukan, Susunan Organisasi, Tugas, Fungsi dan Tata Kerja Dinas Pemberdayaan Masyarakat dan Desa Kabupaten Karawang. Dalam menyelenggarakan tugas pokok sebagaimana dimaksud pada ayat (1) bidang pemberdayaan usaha ekonomi masyarakat desa sebagai rincian tugas substantif sebagai berikut:

a. Pemberdayaan pengelolaan usaha ekonomi masyarakat desa

b. Pendirian, pengurusan dan pengelolaan BUM Desa

c. Pengelolaan pasar desa dan

d. Pengembangan lembaga keuangan mikro perdesaan

Mengkoordinasikan atau memfasilitasi penyelenggaran sebagai berikut:

a. Pemberdayaan pengelolaan usaha ekonomi penduduk miskin desa

b. Pengembangan pengelolaan usaha ekonomi keluarga dan kelompok masyarakat desa

c. Pengembangan pengelolaan usaha produksi dan pemasaran hasil usaha masyarakat desa

d. Pembinaan terhadap SDM dan organisasi pengelolaan BUM Desa, pasar desa serta lembaga keuangan mikro pedesaan.

e. Pemberian bantuan penyertaan modal dari pemerintah dan pemerintah daerah kepada BUM Desa.

f. Penyusunan anggaran dasar dan anggaran rumah tangga BUM Desa.

g. Pemberian pinjaman dan bantuan yang syah dari pihak lain kepada BUMDES

h. Pembentukan BUM Desa bersama antara dua desa atau lebih. (Sumber Pedoman Teknis BUM Desa Kabupaten Karawang)

Responsivitas dari target group dari sebuah program kebijakan merupakan hal yang penting untuk mengukur sejauhmana dari pelaksanaan program tersebut. 
Responsivitas merupakan dari evaluasi program bagian dari rangkaian sebuah evaluasi kebijakan publik. Untuk mengukur sejauhmana resposivitas dari evaluasi program berjalan dengan baik maka parameternya adalah efektivitas, efisiensi kecukupan dan kesamaan serta evaluasi program gagal apabila belum mampu menanggapi kebutuhan aktul dari masyarakat sebagai sasaran dari program tersebut.

Berdasarkan dari hasil penelitian belum resposivitas dari evaluasi program BUM Desa tersebut. Peneliti menemukan beberapa hal yang menunjukan bahwa pelaksanaan dari program BUM Desa tersebut berjalan dengan baik sesuai dengan kebutuhan aktul dari masyarakat sebagai target gruop. Program BUM Desa belum menunjukan implikasi perubahan yang signifikan dari pelaksanaan program tersebut, pelaksanaan program BUM Desa yang menjadi informan BUM Desa di Desa Klari masih di kuasai oleh aparatur pemerintahan desa yang menjadi struktur penggurus.

BUM Desa merupakan lembaga independen diluar dari struktur pemerintahan desa, sumber pendanaan berasal dari APBDes dana Desa bukan berarti pengelola maupun pengurus dari BUM Desa tersebut adalah aparatur desa. Hal ini tidak mencerminkan yang ditegaskan oleh Dunn (2003) dari responsivitas kriterianya efektivitas, efisien, kecukupan dan pemerataan. Maka dari itu dari hasil temuan penelitian penelitian dapat melihat bahwa pelaksanaan program BUM Desa belum mencerminkan resposivitas atas kebutuhan aktual masyarakat serta tidak mencerminkan keadilan dalam pengelolaan BUM Desa masih didominasi oleh kekuatan politik desa yang mengelola dari BUM Desa.

Ketepatan adalah berkenaan dengan pertanyaan apakah program tersebut tepat untuk masyarakat. Apakah program yang telah diimplementasikan pemerintah antara tujuan dan hasil yang diperoleh, benar-benar bernilai/bermanfaat. Dengan kata lain apakah program yang ada benar-benar berguna atau bernilai. Untuk ketepatan alternatif yang digunakan dapat diukur dengan indikator ketepatan dari produk kebijakan. Dalam hal ini berdasarkan hasil penelitian di lapangan peneliti melihat bahwa ketepatan dalam pengklasifikasian jenis usaha BUM Desa sudah sesuai dengan Peraturan Bupati Karawang Nomor 51 Tahun 2015 tentang Pendirian, Pengurusan, Pengelolaan dan Pembubaran Badan Usaha Milik Desa yaitu menjalankan bisnis sosial (social business), menjalankan bisnis penyewaan (renting), menjalankan usaha perantara (brokering), dan menjalankan bisnis yang berproduksi dan / atau berdagang (trading) hanya saja faktanya di lapangan banyak sekali BUM Desa yang mengalami mati suri sehingga ketepatan Dalam Evaluasi Program Badan Usaha Milik Desa di Dinas Pemberdayaan Masyarakat dan Desa Di Kabupaten Karawang belum efektif.

\section{Kesimpulan}

Hasil penelitian menunjukan bahwa evaluasi program BUM Desa oleh Dinas Pemberdayaan Masyarakat dan Desa di Kabupaten Karawang masih belum efektif. Hal ini terlihat dari belum tercapainya tujuan pendirian BUM Desa yang terdiri dari meningkatkan perekonomian desa, mengoptimalkan aset desa agar bermanfaat untuk kesejahteraan desa, meningkatkan usaha masyarakat dalam pengelolaan potensi desa, 
mengembangkan rencana kerja sama usaha antar desa dan atau dengan pihak ketiga, menciptakan peluang dan jaringan pasar yang mendukung kebutuhan layanan umum warga, menciptakan lapangan kerja, meningkatkan kesejahteraan masyarakat melalui perbaikan pelayanan umum, pertumbuhan, pemerataan ekonomi desa serta meningkatkan pendapatan masyarakat desa dan pendapatan asli desa.

\section{Referensi}

Abdul Wahab, Solichin. (2004). Analisis Kebijakan, Dari Formulasi Keimplemen tasi Aksara, Jakarta.

Budi, W. (2014). Kebijakan Publik (Teori, Proses E Studi Kasus). Yogyakarta: CAPS

Dunn, William N. 2003. Pengantar Analisis Kebijakan Publik. Yogyakarta: UGM Press.

Faedlulloh, D. (2018). BUMDes dan Kepemilikan Warga: Membangun Skema Organisasi Partisipatoris. Journal of Governance, 3(1), 1-17. https://doi.org/10.31506/jog.v3i1.3035

Hikmawan, M. D. (2014). Politik Perbedaan: Demokrasi dalam Paradoks. Universitas Gdjah Mada.

Hikmawan, M. D. (2017a). Pluralisme Demokrasi Politik di Indonesia. Journal of Governance, 2(2), 223-247. https://doi.org/http://dx.doi.org/10.31506/jog.v2i2.2678

Hikmawan, M. D. (2017b). Politik Perbedaan: Minnoritas dalam Implementasi Kebijakan. Journal of Indonesian Public Administration and Governance Studies (JIPAGS), 1(1), 88-98.

Hikmawan, M. D., \& Hidayat, R. (2016). Depoliticisation of Public Issue : Low Degree of Government ' S Democratic Legitimacy. Journal of Governance, 1(1), 23-37. https://doi.org/http://dx.doi.org/10.31506/jog.v1i1.1311

Ife, Jim. (1995). Community Development: Creating Community Alternative, Vision, Analysis and Practice. Australisa, Longman.

Moloeng, Lexy J. (2012). Metodologi Penelitian Kualitatif Edisi Revisi. Bandung : PT. Remaja Rosdakarya.

Payne (1997) Modern Social Work Theory , London: Macmillan Press.

Peraturan Menteri Dalam Negeri Nomor 39 Tahun 2010 Tentang Badan Usaha Milik Desa.

Peraturan Menteri Desa Pembangunan Daerah Tertinggal dan Transmigrasi Nomor 19 Tahun 2017 tentang Prioritas Penggunaan Dana Desa 2018 
Peraturan Menteri Desa Nomor 4 Tahun 2015 tentang Badan Usaha Milik Desa.

Peraturan Bupati Karawang Nomor 53 Tahun 2016 Tentang Kedudukan, Sususnan Organisasi, Tugas, Fungsi dan Tata Kerja Dinas Pemberdayaan Masyarakat dan Desa Kabupaten Karawang.

Peraturan Bupati Karawang Nomor 51 Tahun 2015 Tentang Pendirian, Pengurusan, Pengelolaan dan Pembubaran Usaha Milik Desa (BUM Desa)

Riant Nugroho. 2003. Kebijakan Publik: Formulasi, Implementasi dan Evalu asi, Jakarta. Elek Media Komputindo

Slamet. (2003). Pembangunan Masyarakat Berwawasan Partisipasi. Surakarta: Sebelas Maret University Press.

Sugiyono. (2014). Memahami Penelitian Kualitatif. Bandung : Alfabeta.

Widiyanto, A., Hikmawan, M. D., \& Riswanda, riswanda. (2019). JSPG: Journal of Social Politics and Governance Implementasi Rencana Aksi Nasional Bela Negara Berdasarkan Instruksi Presiden Nomor 7 Tahun 2018 Oleh Dewan Ketahanan Nasional Republik Indonesia. Journal of Social Politics and Governance, 1(2), 95-115. 